Artikel Penelitian

\title{
Kaji Perbandingan Karakteristik Respon Dinamik Suspensi Sepeda Motor dengan Memakai Peredam Viscous Oli Sintetis dan Minyak Nabati
}

\author{
Nusyirwan \\ Jurusan Teknik Mesin Fakultas Teknik, Universitas Andalas, Padang 25163
}

INFORMASI ARTIKEL

Sejarah Artikel:

Diterima Redaksi: 04 Agustus 2017

Revisi Akhir: 01 September 2017

Diterbitkan: 31 Oktober 2017

\begin{tabular}{l} 
KATA KUNCI \\
\hline penurunan logaritmic \\
oli peredam \\
shock absorber \\
suspensi \\
KORESPONDENSI \\
\hline
\end{tabular}

E-mail: nusyirwan@ft.unand.ac.id

\begin{abstract}
A B S T R A C T
The motorcycle is a vehicle which is widely used by people today, especially in the narrow streets. This vehicle is able to meet the needs of users because it is cheap, fuel-efficient is also very dynamic to reach places that are difficult to reach by four-wheeled vehicles that have large dimensions. In addition to the many advantages of two-wheeled vehicles should also be taken into account in terms of comfort and safety. Safety factor will depend on many factors, other than humans as a rider, vehicle reliability and the quality level of the road is an important safety factor. Factors vehicle will be in direct contact with the road in its path. Regarding the main factor for the safety of the road is how the vehicle is still stable when it fell into a deep hole or a very rough road. Suspension as one of the main tools to respond to the shock loads on a motorcycle is the main factor that should be taken into account. Types of suspension are used to reduce response style and shock will be felt directly by passengers. This is one study which the suspension is an extremely important characteristic studied. One that plays a role in the election of a suspension damper oil. Oil damper as viscous dampers shock loads can convert into friction and heat. Viscous good silencer is to transfer mechanical energy into heat as much as possible, without changing the characteristics of the damper oil itself. Oils tested, there are three types of commercial oil chosen by the suspension manufacturers. This study was conducted to replace oil with vegetable oil palm oil CPO output can reduce the amplitude of $9.2 \mathrm{~cm}$ for shock loads of $20 \mathrm{~kg}$ with a height of fall of $3 \mathrm{~m}$. Fall height of $3 \mathrm{~m}$ damping ratio of vibration damper formed by CPO was 0.41 .
\end{abstract}

\section{PENDAHULUAN}

\subsection{Latar Belakang}

Sepeda motor merupakan kendaraan yang banyak dipakai oleh masyarakat pada zaman sekarang terutama untuk jalan-jalan yang sempit dengan tingkat mobilitas yang tinggi. Dalam mengoperasikan sepeda motor banyak kendala yang dihadapi, salah satunya adalah kendaraan tersebut dioperasikan untuk memasuki jalan - jalan dengan tingkat kekasaran yang tinggi (off road) dan jalan yang berlubang serta tidak rata. Oleh karena itu, tingkat kenyaman dan keamanan perlu dipertimbangkan. Untuk mengurangi getaran dan guncangan, sepeda motor harus dilengkapi dengan sistem suspensi, salah satunya adalah shock absorber.

Shock Absorber berfungsi untuk memperlambat dan mengurangi besarnya getaran dengan mengubah energi kinetik dari gerakan suspensi menjadi energi 
panas yang dapat dihamburkan melalui cairan hidrolik [1].

Salah satu yang menjadi kajian penelitian ini adalah seberapa besar tingkat penyerapan gelombang getaran yang diberikan pada suatu bodi sepeda motor dengan menggunakan shock absorber dengan memvariasikan viskositas peredamnya.

\subsection{Tujuan}

Tujuan yang diharapkan dapat tercapai dari penelitian ini adalah:

1. Menentukan besarnya penurunan amplitudo gelombang getaran akibat beban kejut yang diberikan pada shock absorber.

2. Menganalisa pengaruh variasi viskositas sebagai peredam pada shock absorber sepeda motor.

\subsection{Manfaat}

Melalui penelitian ini, dapat diketahui dan dapat ditentukan jenis oli peredam yang cocok pada shock absorber sepeda motor tertentu.

\subsection{Ruang Lingkup Pembahasan}

Dalam penelitian ini, oli peredam yang digunakan adalah oli peredam original dari shock absorber sebagai suspensi sepeda motor komesrsial, dan oli suspensi dari minyak nabati seperti ;minyak kelapa sawit (CPO), dan minyak goreng. Beban yang akan digunakan sebagai beban kejut akan divariasikan dengan massa $5 \mathrm{~kg}, 10 \mathrm{~kg}, 15 \mathrm{~kg}$, dan $20 \mathrm{~kg}$.

\section{METODOLOGI}

Viskositas adalah ukuran kekentalan suatu fluida yang menunjukkan besar kecilnya gesekan internal fluida [2]. Viskositas adalah ukuran yang menyatakan kekentalan suatu cairan atau fluida. Kekentalan merupakan sifat cairan yang berhubungan erat dengan hambatan untuk mengalir. Beberapa cairan ada yang mengalir dengan cepat, sedangkan lainnya mengalir secara lambat. Cairan yang mengalir cepat contohnya seperti air, alkohol, dan bensin karena memiliki nilai viskositas kecil. Sedangkan cairan yang mengalir lambat seperti gliserin, minyak asto dan madu karena mempunyai nilai viskositas yang besar. Jadi viskositas tidak lain menentukan kecepatan mengalirnya suatu cairan [Yazid, 2005].

Kekentalan terjadi karena kohesi antar partikel zat cair. Zat cair ideal tidak mempunyai kekentalan. Zat cair mempunyai beberapa sifat sebagai berikut [Wylie, 1992]:

1. Apabila ruangan lebih besar dari volume zat cair akan terbentuk permukaan bebas horizontal yang berhubungan dengan atmosfer.

2. Mempunyai rapat massa dan berat jenis.

3. Dapat dianggap tidak termampatkan.

4. Mempunyai viskositas (kekentalan).

5. Mempunyai kohesi, adesi, dan tegangan permukaan.

\subsection{Metode Pengukuran Viskositas dengan Metode Ostwald}

Metode ini ditentukan berdasarkan hukum Poisulle menggunakan alat viskometer oswaltd. Penetapannya dilakukan dengan jalan mengukur waktu yang diperlukan untuk mengalirkan cairan dalam pipa kapiler dari a ke b. Sejumlah cairan yang akan diukur viskositasnya dimasukkan kedalam viskometer yang diletakkan pada thermostat. Cairan kemudian diisap degan pompa kedalam bola sampai diatas tanda a. Cairan dibiarkan mengalir kebawah dan waktu yang diperlukan dari a ke b dicatat menggunakan stowatch [Rosian, 2009]. 
Tabel 1. Viskositas cairan pada berbagai suhu (satuan poise) [Bird, 1987]

\begin{tabular}{|l|c|c|c|c|c|c|}
\hline Cairan & $0^{\circ} \mathrm{C}$ & $10^{\circ} \mathrm{C}$ & $20^{\circ} \mathrm{C}$ & $30^{\circ} \mathrm{C}$ & $40^{\circ} \mathrm{C}$ & $50^{\circ} \mathrm{C}$ \\
\hline Air & 0,0179 & 0,013 & 0,0101 & 0,0080 & 0,0065 & 0,0055 \\
\hline Gliserin & 105,9 & 34,4 & 13,4 & 6,29 & 2,89 & 1,41 \\
\hline Anilin & 0,102 & 0,065 & 0,0044 & 0,0316 & 0,0227 & 0,0185 \\
\hline Bensin & 0,0091 & 0,0076 & 0,0065 & 0,0056 & 0,0050 & 0,0044 \\
\hline Etanol & 0,0177 & 0,0147 & 0,012 & 0,0100 & 0,0083 & 0,007 \\
\hline $\begin{array}{l}\text { Minyak } \\
\text { lobak }\end{array}$ & 25,3 & 3,85 & 1,63 & 0,96 & - & - \\
\hline
\end{tabular}

Pada metode oswaltd yang diukur adalah waktu yang diperlukan oleh sejumlah tertentu cairan untuk mengalir melalui pipa kapiler dengan gaya yang disebabkan oleh berat cairan itu sendiri. Pada percobaan sejumlah tertentu cairan dipipet kedalam viskometer. Cairan kemudian dihisap melalui labu ukur dari viskometer sampai permukaan cairan lebih tinggi dari batas "a". Cairan dibiarkan turun ketika permukaan cairan turun melewati batas "b", stopwatch dimatikan. Jadi waktu yang dibutuhkan cairan untuk melewati jarak antara a dari b dapat ditentukan. Tekanan $\mathrm{P}$ merupakan perbedaan tekanan antara kedua ujung pipa $U$ dan besarnya diasumsikan sebanding dengan berat jenis cairan [Ronana, 2009].

\subsection{Shock Absorber}

Shock absorber merupakan komponen penting suatu kendaraan yaitu dalam sistem suspensi, yang berguna untuk meredam gaya osilasi dari pegas. Shock absorbers berfungsi untuk memperlambat dan mengurangi besarnya getaran gerakan dengan mengubah energi kinetik dari gerakan suspensi menjadi energi panas yang dapat dihamburkan melalui cairan hidrolik [4].

Shock absorber adalah alat yang berfungsi sebagai peredam guncangan atau kejutan dan untuk mendispersikan energi kinetik yang dihasilkan guncangan atau kejutan tersebut. Shock absorber berperan penting pada sistem suspensi mobil dan motor, roda pendaratan untuk pesawat terbang, dan sebagai bagian dari sistem pendukung mesin-mesin industri.Versi besar dari shock absorber terkadang digunakan dalam teknik struktural untuk menambah stabilitas dan mengurangi kerusakan yang diakibatkan oleh bencana alam. Shock absorber biasanya berbentuk silinder yang terdiri dari piston bergerak yang dilapisi oleh cairan hidrolik atau udara [5].

Konstruksi shock absorber itu terdiri atas piston, piston rod dan tabung. Piston adalah kmponen dalam tabung shock absorber yang bergerak naik turun di saat shock absorber bekerja. Sedangkan tabung adalah tempat dari minyak shock absorber dan sekaligus ruang untuk piston bergerak naik turun. Dan yang terakhir adalah piston rod adalah batang yang menghubungkan piston dengan tabung bagian atas (tabung luar) dari shock absorber. Dapat terlihat pada Gambar 1.

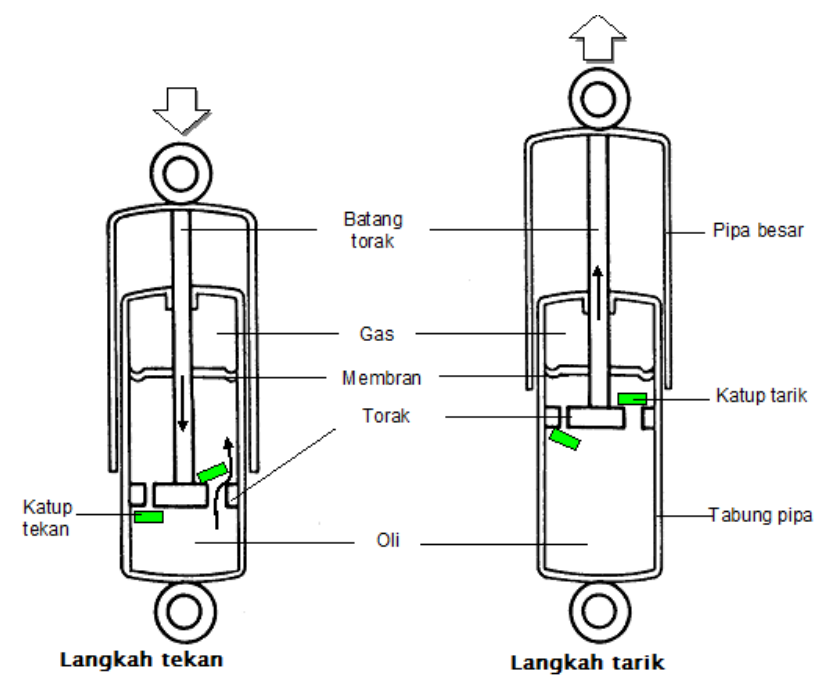

Gambar 1. Shock Absorber 


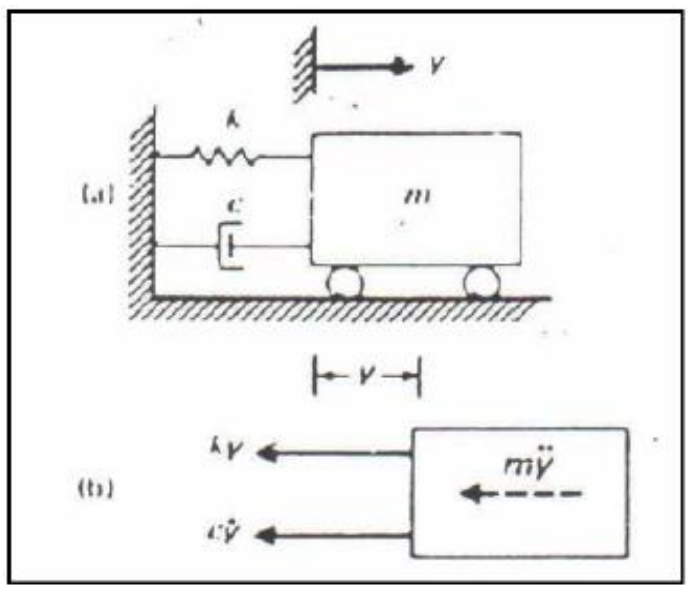

Gambar 2. Sistem Getaran Massa dan Pegas 1 DOF

Formula yang digunakan untuk menghitung nilai dari konstanta sebuah shock absorberdapat dilihat pada persamaan 2.1.

$C=\frac{F D}{\dot{x}}$

Karena $\dot{x}$ belum diketahui, maka digunakan persamaan (2.2) untuk mendapatkan $\dot{x}$.

$\dot{x}=\frac{x}{t}$

Dengan menjumlahkan semua gaya yang berlaku pada benda kita mendapatkan persamaan:

$m \ddot{x}+c \dot{x}+k x=0$

Solusi persamaan ini tergantung pada besarnya redaman. Bila redaman cukup kecil, sistem masih akan bergetar, namun pada akhirnya akan berhenti. Keadaan ini disebut kurang redam, dan merupakan kasus yang paling mendapatkan perhatian dalam analisis vibrasi. Bila peredaman diperbesar sehingga mencapai titik saat sistem tidak lagi berosilasi, kita mencapai titik redaman kritis. Bila peredaman ditambahkan melewati titik kritis ini sistem disebut dalam keadaan lewat redam.
Nilai koefisien redaman yang diperlukan untuk mencapai titik redaman kritis pada model massapegas-peredam adalah:

$c_{c}=2 \sqrt{\mathrm{km}}$

Persamaan untuk nisbah redaman $(\zeta)$ adalah

$$
\zeta=\frac{c}{2 \sqrt{k m}}
$$

Solusi sistem kurang teredam pada model massapegas-peredam adalah

$x(t)=X_{\varepsilon}^{-\zeta \omega_{n} t} \cos \left(\sqrt{1-\zeta^{2}} \omega_{n} t-\phi\right)$

Dengan harga

$\omega_{n}=2 \pi f_{n}$

\subsection{Pengurangan Logaritmik (Logarithmick Decrement)}

Metode praktek untuk mentukan secara eksperintal koefisien redaman dari satu sistem adalah dengan memberikan getaran bebas, kemudian didapatkan grafik dari gerak osilasi seperti terlihat pada Gambar 3 serta mengukur besar pengurangan amplitudo dari gerak tersebut.Pengurangan dapat terlihat jelas sekali dengan pengurangan logaritmik (logarithmick decrement) yang didefenisikan sebagai logaritma natural dari ratio dua puncak amplitude yang berurutan $A_{1}$ dan $A_{2}$ dari getaran bebas. Pengurangan logaritmik tersebut dapat ditentukan dengan menggunakan persamaan berikut:

$$
\delta=\ln \frac{A_{1}}{A_{2}}
$$




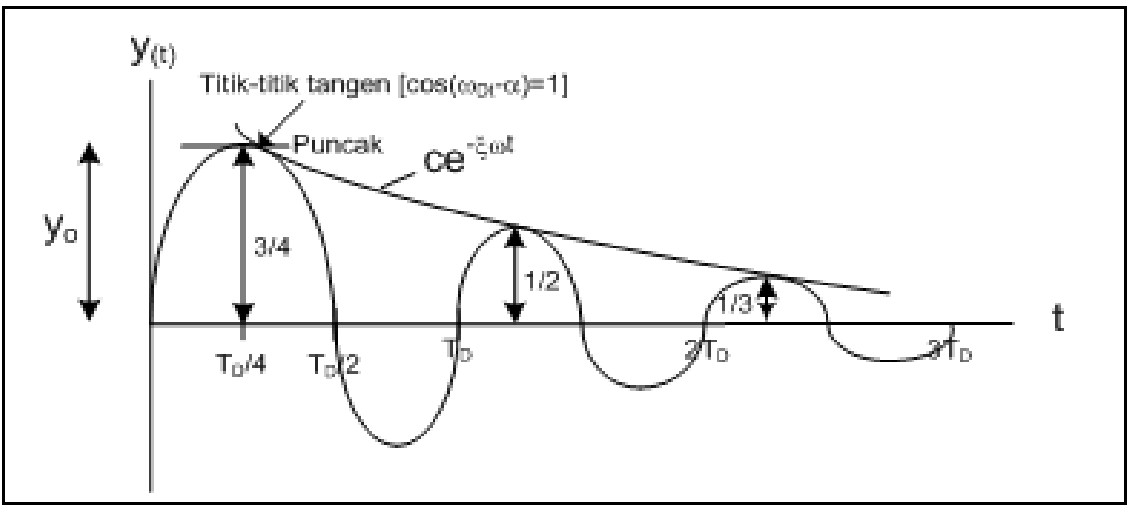

Gambar 3. Penurunan Logaritmik

Lengkungan menunjukan perpindahan puncak dan perpindahan pada titik tangensial [8]. Bagilah kedua amplitudo dan ambil harga logaritma naturalnya, sehingga didapatkan:

$\delta=\ln \frac{A_{1}}{A_{2}}=\zeta \omega T_{D}$

atau dengan substitusi periode redaman $T_{D}$ dari persamaan berikut

$T_{D}=\frac{2 \pi}{\omega D}=\frac{2 \pi}{\omega \sqrt{1-\zeta^{2}}}$

Sehingga diperoleh

$\delta=\frac{2 \pi}{\sqrt{1-\zeta^{2}}}$

Sehingga cara lain untuk menentukan rasio redaman dari suatu sistem dapat kita tentukan dengan menggunakan persamaan penurunan logaritmik, yaitu:

$\zeta=\frac{\delta}{\sqrt{(2 \pi)^{2}+\delta^{2}}}$

\subsection{Metode Pengujian}

Metode pengujian dilakukan dengan menggunakan beban massa $5 \mathrm{~kg}, 10 \mathrm{~kg}, 15 \mathrm{~kg}$, dan $20 \mathrm{~kg}$, dimana beban tersebut akan dijatuhkan ke plat besi sebagai beban kejut yang telah ditumpu oleh poros dan poros tersebut disambungkan ke shock absorber.
Beban kejut yang dihasilkan akan tersalurkan ke shock absorber dan pena pencatat yang telah dipasangkan ke shock absorber akan mencatat gelombang yang dihasilakan akibat beban kejut tersebut pada kertas grafik yang digulung pada drum penggulung kertas.

\subsubsection{Set-up Alat}

1. Masukan oli original shock absorber SAE 10 ke dalam shock absorber sebanyak $70 \mathrm{ml}$.

2. Pasang shock absorber pada alat uji.

3. Pastikan shock absorber terpasang dengan benar.

4. Sambungkan poros yang telah tersambung dengan plat besi pada shock absorber sebagai penumpu beban.

5. Pastikan poros penumpu beban terpasang dengan benar.

6. Sambungkan slide regulator dengan drum pemutar kertas.

7. Pastikan seluruh alat terpasang dengan benar.

\subsubsection{Prosedur Pengujian}

1. Set - up alat uji.

2. Siapkan beban sebagai beban kejut sebesar 5 $\mathrm{kg}, 10 \mathrm{~kg}, 15 \mathrm{~kg}$ dan $20 \mathrm{~kg}$.

3. Pasangkan kertas grafik pada drum pemutar kertas.

4. Sambungkan pena yang tersambung pada shock absorber pada kertas grafik.

5. Jatuhkan beban pada poros penumpu beban. Bersamaan dengan beban dijatuhkan, jalankan 
slide regulator untuk memutar drum kertas grafik.

6. Didapatkan grafik yang tercatat pada kertas grafik akibat beban kejut.

7. Ganti oli yang digunakan sebelumnya pada shock absorber dengan minyak kelapa sawit (CPO) sebanyak $70 \mathrm{ml}$.
8. Set $-u p$ alat.

9. Lakukan prosedur $2-6$ kembali hingga mendapatkan grafik yang berbeda.

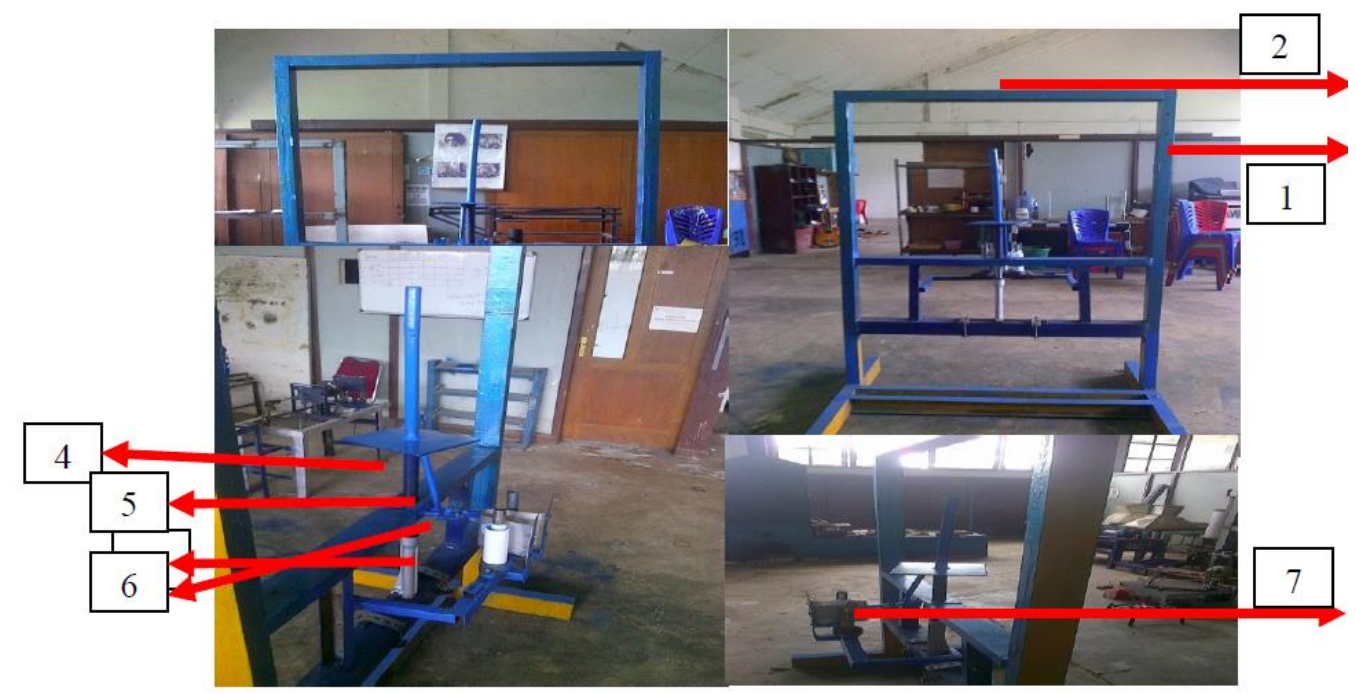

Gambar 4. Peralatan pengujian

Keterangan: (1) Kerangka alat uji, (2) Shock Absorber, (3) Poros alur beban, (4) Plat besi, (5) Poros penyangga beban, (6) Pena pencatat grafik, (7) Drum pemutar kertas grafik
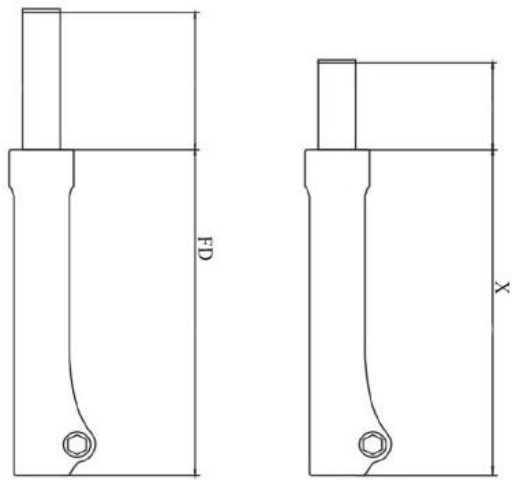

Gambar 5. Shock absorber

\section{HASIL DAN PEMBAHASAN}

Untuk mentukan pengaruh redaman efek gerakan dari suspensi perlu dikaji berapa amplitudo getaran yang ditimbulkan batang suspensi pada shock absorber terhadap tinggi jatuh beban dengan beban yang bervariasi dari mulai $15 \mathrm{~kg}, 10 \mathrm{~kg}, 15 \mathrm{~kg}$ darn yang terbesar sebesar $20 \mathrm{~kg}$ yang dijatuhkan pada ketinggian $1 \mathrm{~m}, 2 \mathrm{~m}$ dan $3 \mathrm{~m}$ untuk menghasilkan energi impak. 
Tabel 2. Hasil Pengujian Karakteristik Getaran Suspensi Sepeda Motor

\begin{tabular}{|c|c|c|c|c|}
\hline Oli Peredam & Beban & $\begin{array}{l}\text { Amplitudo, } \\
\text { cm }\end{array}$ & $\begin{array}{c}\delta, \text { Penurunan } \\
\text { logaritmik }\end{array}$ & $\begin{array}{l}\zeta, \text { Rasio } \\
\text { redaman }\end{array}$ \\
\hline \multirow{8}{*}{$\begin{array}{l}\text { Oli Sintetis } \\
\text { (Oil Shock Absorber) }\end{array}$} & \multirow{2}{*}{$5 \mathrm{Kg}$} & $\mathrm{A} 1=2.93$ & \multirow{2}{*}{1.07} & \multirow{2}{*}{0.27} \\
\hline & & $\mathrm{A} 2=1$ & & \\
\hline & \multirow{2}{*}{$10 \mathrm{Kg}$} & $\mathrm{A} 1=2.7$ & \multirow{2}{*}{0.82} & \multirow{2}{*}{0.23} \\
\hline & & $\mathrm{A} 2=2.3$ & & \\
\hline & \multirow{2}{*}{$15 \mathrm{Kg}$} & $\mathrm{A} 1=3.5$ & \multirow{2}{*}{0.99} & \multirow{2}{*}{0.35} \\
\hline & & $\mathrm{A} 2=3.8$ & & \\
\hline & \multirow{2}{*}{$20 \mathrm{Kg}$} & $\mathrm{A} 1=4.2$ & \multirow{2}{*}{0.65} & \multirow{2}{*}{0.53} \\
\hline & & $\mathrm{A} 2=4.7$ & & \\
\hline \multirow{8}{*}{ CPO } & \multirow{2}{*}{$5 \mathrm{Kg}$} & $\mathrm{A} 1=4.3$ & \multirow{2}{*}{2.23} & \multirow{2}{*}{0.28} \\
\hline & & $\mathrm{A} 2=5.1$ & & \\
\hline & \multirow{2}{*}{$10 \mathrm{Kg}$} & $\mathrm{A} 1=3.86$ & \multirow{2}{*}{0.88} & \multirow{2}{*}{0.37} \\
\hline & & $\mathrm{A} 2=2.6$ & & \\
\hline & \multirow{2}{*}{$15 \mathrm{Kg}$} & $\mathrm{A} 1=3.7$ & \multirow{2}{*}{1.04} & \multirow{2}{*}{0.31} \\
\hline & & $\mathrm{A} 2=5.5$ & & \\
\hline & \multirow{2}{*}{$20 \mathrm{Kg}$} & $\mathrm{A} 1=7.9$ & \multirow{2}{*}{0.34} & \multirow{2}{*}{0.41} \\
\hline & & $\mathrm{A} 2=9.2$ & & \\
\hline \multirow{8}{*}{ Minyak Goreng } & \multirow{2}{*}{$5 \mathrm{Kg}$} & $\mathrm{A} 1=3.1$ & \multirow{2}{*}{1.43} & \multirow{2}{*}{0.22} \\
\hline & & $\mathrm{A} 2=3.6$ & & \\
\hline & \multirow{2}{*}{$10 \mathrm{Kg}$} & $\mathrm{A} 1=3.7$ & \multirow{2}{*}{0.95} & \multirow{2}{*}{0.14} \\
\hline & & $\mathrm{A} 2=4.5$ & & \\
\hline & \multirow{2}{*}{$15 \mathrm{Kg}$} & $\mathrm{A} 1=5.4$ & & \\
\hline & & $\mathrm{A} 2=7.4$ & 0.07 & 0.015 \\
\hline & $20 \mathrm{~K}$ & $\mathrm{~A} 1=7.6$ & 057 & 001 \\
\hline & & $\mathrm{A} 2=8.62$ & & \\
\hline
\end{tabular}

Pengujian dilakukan dengan 3 variasi oli yang digunakan sebagai peredam dari shock absorber dimana viskositas dari masing - masing oli berbeda. Beban yang digunakan sebagai beban kejut adalah besi padu dimana beratnya divariasikan sebesar 5 $\mathrm{kg}, 10 \mathrm{~kg}, 15 \mathrm{~kg}$, dan $20 \mathrm{~kg}$. Adapun hal yang menjadi bahasan dalam pengujian ini adalah penurunan amplitudo pada shock absorber dan pengaruh variasi viskositas peredam shock absorber. Pada Tabel 2 peredam dengan mengunakan oli sintetik diperoleh $\zeta$, (Rasio redaman) sebesar 0,1 , sedangkan pada oli CPO untuk beban maksimal $20 \mathrm{~kg}$ hanya sebesar 0,05 dan yang lebih kecil lagi pada minyak goreng sebesar 0,09. Dari hasil pengujian diperoleh rasio redaman terbesar dapat dihasilkan dari oli sintetis. Tetapi dari oli CPO dapat setengahnya dari oli sintetis.
Pada pengujian ini didapatkan besarnya amplitudo pada tiap - tiap beban yang diberikan untuk masing - masing viskositas. Perbedaan besarnya amplitudo tersebut dapat dilihat pada grafik sebagai berikut:

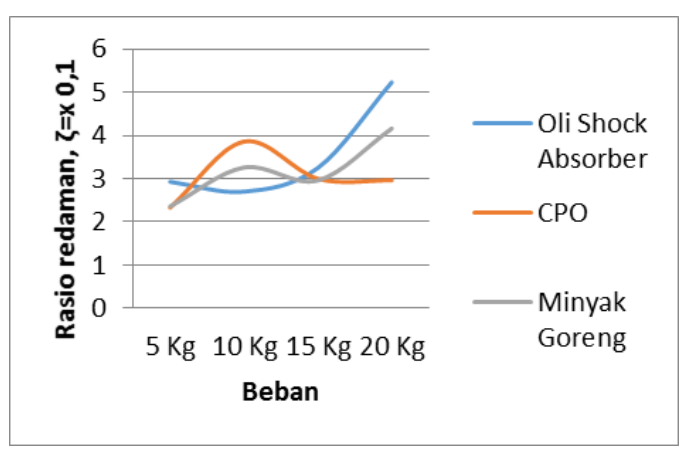

Gambar 6. Contoh Penulisan Caption Pada Gambar 
Dari grafik pada Gambar 6 untuk tinggi jatuh beban setinggi $3 \mathrm{~m}$, terlihat bahwa pada beban $5 \mathrm{~kg}$ sampai $15 \mathrm{~kg}$ hanya terjadi sedikit perbedaan amplitudo, tetapi pada beban sebesar $20 \mathrm{~kg}$ dengan rasio redaman terbesar pada oli sintetis 0,53 .

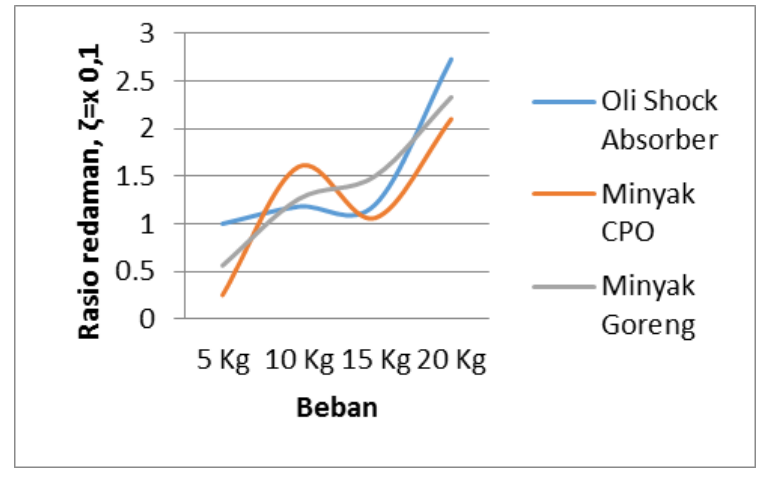

Gambar 7. Grafik Rasio Redaman Terhadap Variasi Beban pada Ketinggian Jatuh Beban, 2 m

Dari grafik pada Gambar 7 untuk tinggi jatuh beban setinggi $2 \mathrm{~m}$, terlihat bahwa pada beban $5 \mathrm{~kg}$ sampai $15 \mathrm{~kg}$ hanya terjadi sedikit perbedaan amplitudo, tetapi pada beban sebesar $20 \mathrm{~kg}$ dengan rasio redaman terbesar pada oli sintetis 0,27.

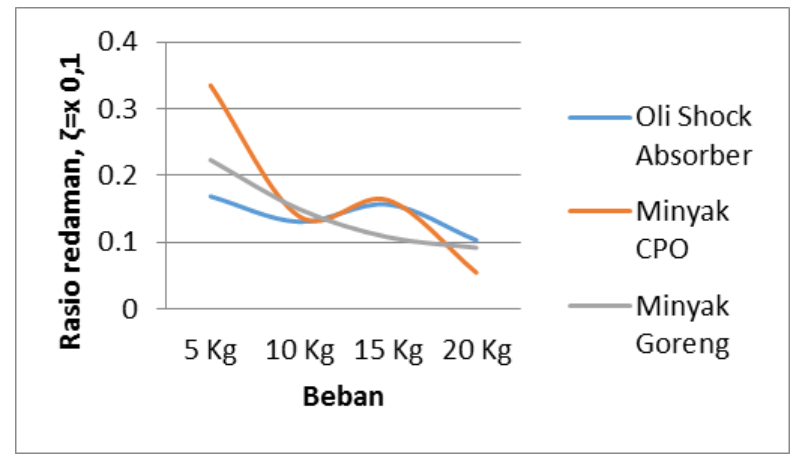

Gambar 8. Grafik Rasio Redaman Terhadap Variasi Beban pada Ketinggian Jatuh Beban, 1 m

Dari grafik pada Gambar 8 untuk tinggi jatuh beban setinggi $1 \mathrm{~m}$, terlihat bahwa pada beban $5 \mathrm{~kg}$ sampai $15 \mathrm{~kg}$ hanya terjadi sedikit perbedaan amplitudo, tetapi pada beban sebesar $20 \mathrm{~kg}$ dengan rasio redaman terbesar pada oli sintetis 0,01 .

\section{KESIMPULAN DAN SARAN}

Dari hasil pengujian diperoleh variasi viskositas sebagai oli peredam dari shock absorber dan variasi beban sebagai beban kejut, maka diperoleh kesimpulan sebagai berikut Oli sintetis ampilituo terbesar untuk ketinggian jatuh beban setinggi $3 \mathrm{~m}$ adalah 4,7 cm dengan damping rasio sebesar, 0,53. Untuk minyak CPO amplitudo terbesar sebesar 9,2 $\mathrm{cm}$ dan rasio redamannya dalah 0,41 . selanjutnya untuk minyak goreng amplitudo terbesar amplitudo terbesar $8,2 \mathrm{~cm}$ sedangkan rasio redamannya sebesar 0,01 .

Dari beberapa data diatas bahwa minyak nabati yang berasal dari CPO menghasilkan rasio redaman $75 \%$ dari rasio redaman oli sintetik berarti minyak CPO dapat mempunyai nilai potensial menggantikan oli sintetis.

\section{UCAPAN TERIMA KASIH}

Penelitian ini dibiayai oleh dana DIPA fakultas Teknik Unand tahun 2016. Ucapan terima kasih kami sampaikan kepada Dekan Fakultas Teknik dan Ketua Jurusan Teknik Mesin universitas andalas yang memberikan bantuan moril dan material untuk berjalannya proses penelitian ini.

\section{DAFTAR PUSTAKA}

Jurnal

[1] Nusyirwan, "Kaji Teoritik Frekuensi Pribadi dan Modus Getar Silinder Berdinding Tipis dengan Metode Geometri”, Jurnal Teknika, No.34 Vol I THN XVII, Fakultas Teknik Universitas Andalas, 2010.

[2] Nusyirwan, "Metode Penurunan Respon Dinamik Sistem Poros- Rotor dengan Peredam Viscous Rotary", Jurnal Poros Universitas taruma Negara, No.10, Edisi November 2014.

[3] Nusyirwan, "Kajian Pengering gabahDengan wadah berbentuk Silinder Mengunakan Pengaduk Putar", Jurnal,Cylinder, Vol. 1 No. 2 Edisi Oktober 2014, Unika Admajaya Jakarta 2014 
Thesis

[4] G. Subrata, "Korelasi Hasil Kaji Teoritik dan Eksperimental Getaran Pelat Model T', Tugas Sarjana S2, ITB, Thn, 1990

[5] D. Setyanto. "Kaji Teoritik dan Eksperimental Perilaku dinamik Bodi Mobil Daihatsu Zebra", Tugas Sarjana, S2 ITB, THn,1992.

[6] N. Eddy "Pengukuran Fungsi Transper dan Model Elemn Hinggauntuk Analisis Dinamik Body Mobil", Tugas Sarjan , S2, ITB, 1992

[7] F. R. Sumendap "Kaji Perbandingan Metode Curve Fitting dengan redaman Viscous Proprtional dan Redaman Kasus Umum", Tugas Sarjana, S1, ITB, 1991

[8] Nusyirwan. "Penggunaan Parameter Modus Getar Untuk Analisis Sensitifitas Struktur Mekanik", Tugas Sarjana, S2, ITB, THn 1995 $\omega, \quad$ kecepatan sudut.

$\omega_{d}$, frekuensi pribadi teredam.

$\in, \quad$ bilangan mendekati nol.

$\tau_{a}$, time konstan.

$\zeta, \quad$ rasio redaman.

\section{NOMENKLATUR}

Nomenklatur disertai arti dari semua persamaan matematika ataupun nomenklatur lain di alam artikel, dituliskan pada bagian ini.

e kesalahan.

F gaya.

G fungsi dimensi lengan.

$\mathrm{G}(\mathrm{s}) \quad$ fungsi transfer.

K faktor penguatan.

$\mathrm{R} \quad$ jari-jari gerak melingkar.

$\mathrm{O}$ pusat putar.

S lintasan gerak.

U kecepatan putar lengan.

$\mathrm{V} \quad$ kecepatan translasi.

$V_{b}{ }^{x} \quad$ kecepatan vector arah sumbu $\mathrm{x}$.

$V_{b}{ }^{y} \quad$ kecepatan vector arah sumbu y.

$X_{A} \quad$ panjang vector titik A pada sumbu $\mathrm{x}$.

$x_{B} \quad$ panjang vector titik B pada sumbu $\mathrm{x}$.

$Y_{A}$, panjang vector titik A pada sumbu $\mathrm{y}$.

$y_{B}$, panjang vector titik B pada sumbuy.

$\mathrm{t}$, waktu tempuh.

$\Theta, \quad$ sudut rotasi.

$\theta_{c}$, perubahan sudut rotor output terhadap waktu.

$\theta_{e}$, perubahan sudut rotor input terhadap waktu. 